\title{
RANGE EXTENSION OF THE WANDERING SHREW
}

\author{
by Harvey Beck, Univ. of Sask., Saskatoon
}

The Wandering Shrew (Sorex vagrans) has previousily been reported in Saskatchewan from the Cypress Hills and Prince Albert $\mathrm{Na-}$ tional Park (Anderson and Rand, 1945. A new form of dusky shrew from prairie provinces of Canada. Can. Field-Nat., 59:47-48).

Four specimens were collected at Stony Rapids and five at La Ronge during the summer of 1960 . These records extend the known range some 350 .miles north and 150 miles east. The shrews from Stony Rapids were collected by Wayne Davis in the course of a survey conducted for the Institute of Northern Studies, University of Saskatchewan.

The average and extreme measurements (in millimeters) for the specimens from each locality are:

Stony Rapids - total length, 101.2 (100-13); tail, 42.8 (41-45); hind foot, $13.2(12-14)$.

La Ronge-total length, 109 (107112); tail, 45 (43-48); hind foot, 13.1 (12.5-13.5).

\section{PET MINK AND RACOON AT KENOSEE}

by May Neal, Regina

In the spring of 1961 one of the inmates of Kenosee work camp, operated in conjunction with the Regina Jail, found a little brown mink by the roadside. The mother had been run over. He put the little creature in his pocket, took her back to the camp, where she became everyone's pet. The men also made a pet of a young racoon.

At first they fed the mink with milk from an eyedropper. They gave her scraps from the table and grain and greens. She lived in a pen until the men found they could let her, and the coon, run around among them outside the cook house after meals or evenings. Running around this way the animals got nibbles of biscuit and an occasional bit of a chocolate bar. They grew fat, shiny and friendly.
By mid-summer when I saw the pets, the mink had the breed's sharp little teeth and claws that could rip a gash but she was used to being handled and did not rip or claw. I picked her up, stroked and petted her, put her round my neck as I would a kitten. This was entirely different from my only previous experience with mink at a mink show. To hold one of the show mink I needed staunch leather gauntlets. The little coon, too, was just as friendly though its coarser fur made it less kitten-like or "cuddly."

Both animals swam naturally and the men took them swimming with them in the nearby lake on the hot summer evenings. Many people from the nearby holiday resorts came to see these interesting pets.

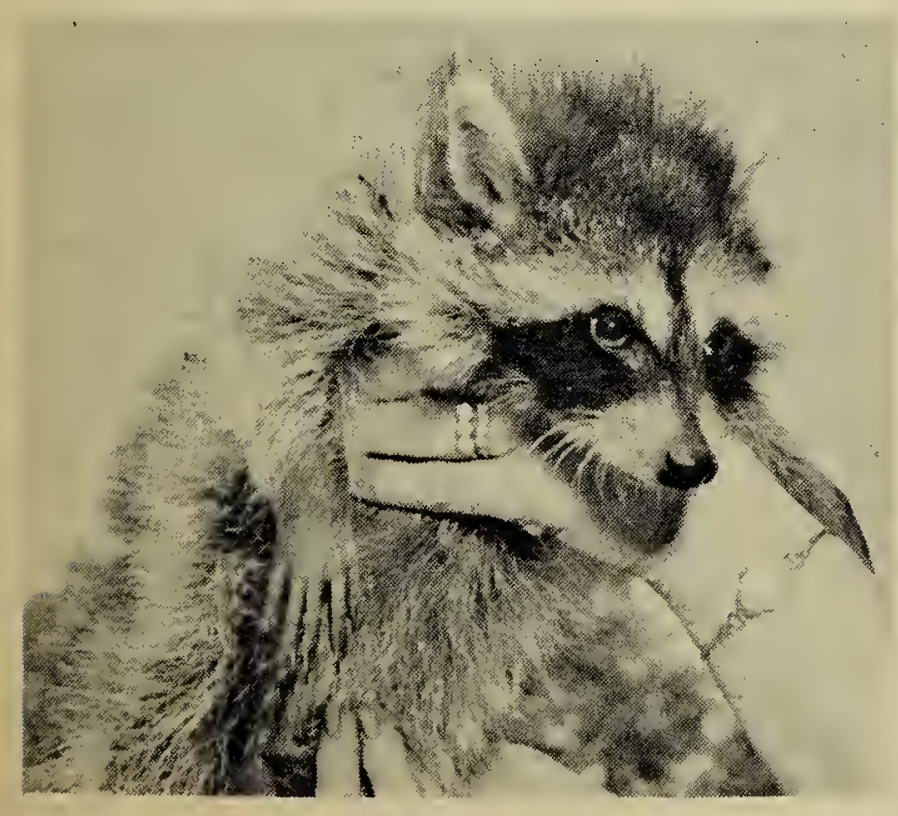

Sask. Gov't. Photo

Pet Racoon at Kenosee, 1961.

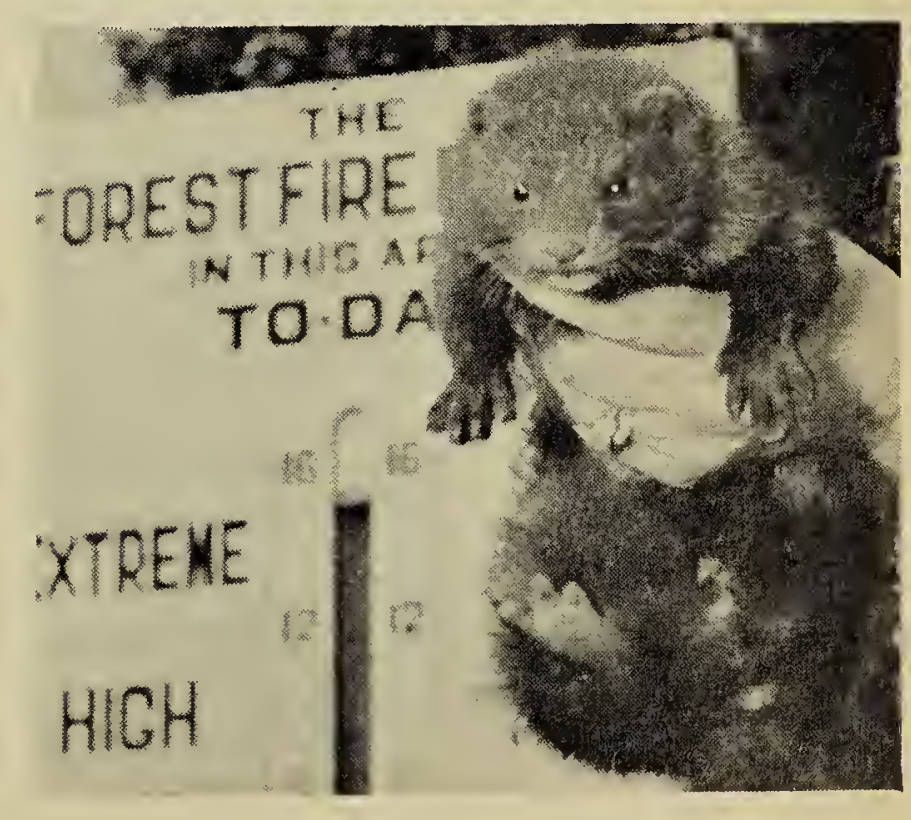

Sask. Gav't. Phato

Pet Mink at Kenosee, 1961. 